\title{
Suggestion on Socialist Legal Culture Construction Path with Chinese Characteristics
}

\author{
Ximei Zhang \\ Chifeng University \\ Chifeng, China 024000
}

\begin{abstract}
To build socialist legal culture with Chinese characteristics, it needs to adhere to the principle of combining cultural self-consciousness with comprehensive innovation, treat traditional culture and foreign culture scientifically; construct social foundation of the legal culture and establish civil society; create the legal environment that develops legal culture; persist in cultivating the legal culture of citizens as a basic and fundamental foothold.
\end{abstract}

Keywords-socialist legal culture with Chinese characteristics; construction path

\section{INTRODUCTION}

At present, the major event of China's social construction shall be the establishment of the rule of law and the cultivation of cultural confidence. The construction of the socialist legal culture with Chinese characteristics is not only one of the most important contents of cultural development, but also the foundation for building society with rule of law. This paper attempts to put forward several opinions on the path of building socialist legal culture with Chinese characteristics.

\section{AdHERE TO THE PRINCIPLE OF COMBINING CULTURAL} SELF-CONSCIOUSNESS WITH COMPREHENSIVE INNOVATION AND TREAT TRADITIONAL CULTURE AND ForEIGN CULTURE SCIENTIFICALLY

Cultural self-consciousness and comprehensive innovation are the important concepts of strategic guiding significance for the development of Chinese culture that are respectively proposed by renowned scholar Mr. Fei Xiaotong and Mr. Zhang Dainian. Cultural self-consciousness means that people must have sufficient self-knowledge and cultural confidence about the local culture within the domain and have a keen discernment, broad and deep inclusiveness and enough absorbing force on the world culture outside the domain. Culture is the spiritual gene of the nation and the spiritual home of the people. Cultural confidence is a great spiritual force for the growth and development and continuity of a nation. The lack of cultural confidence in any nation is equivalent to the absence of a spiritual backbone. For selfknowing, we should have a clear understanding of local culture and see our shortcomings, so as to avoid blind arrogance. Comprehensive innovation means that it neither practices "western centralism" nor "eastern centralism", but should be the innovation based on the fusion of the eastern and western excellent human culture. To strengthen the construction of socialist legal culture with Chinese characteristics, it shall adhere to the principles of cultural self-consciousness and comprehensive innovation, constantly improve cultural consciousness and innovation ability, make great efforts to research, develop and carry forward Chinese traditional culture, construct a perfect and scientific discourse system and a theoretical system for the rule of law in China, and create a socialist legal culture with Chinese characteristics.

\section{A. Fully Consider the Connection with Traditional Culture}

Culture has never been a negative and passive existence in social life, and has been designing and influencing the economy, politics, and people's daily life, which is the socalled cultural power. The longer the cultural tradition exists, the greater the influence is. "If we ignore the role of internal factor of national culture and adopt a simple transplant of 'copinism' in the process of the construction of rule of law, one of its direct consequences is the disorder of the whole state's cultural system."1 Therefore, we must fully consider the traditional culture which has a long history and has been deeply integrated into the national blood during the construction of socialist legal culture with Chinese characteristics.

Firstly, we should make full use of the traditional thought of "rule of virtue". Confucianism is the core of Chinese traditional culture, and its thought of "rule of virtue" has played a significant role in the formation of Chinese political and legal system in the past dynasties. The political views of "rule by law and rite", from Confucian's "exercising government by means of virtue" to Mencius's "benevolent government", Xuncius's "prospering etiquettes and respecting laws", Dong Zhongshu's "morality given priority over penalty", all strongly advocated that the rulers should implement the "rule by rites", that is, use moral education to govern the state. The "rule of virtue" will evolve into the mode of "rule by man" because of the ruler's own limitations. However, its idealistic origin is to regard the morality as the spirit and soul of law, which is consistent with the value pursuit of modern rule of law, that is, the morality is the basic attribute of good law. Therefore, we should make full of the traditional thought of rule of virtue, guide legislation with "moral", and regulate people's behavior with the morals established in the legal norms in the process of the construction of the legal culture. However, it must be clear that emphasizing the "rule of virtue" does not mean the abolishment of "law" because of "virtue". The one-sided 
emphasis on the role of morality will break the bottom line of the rule of law and eventually slip into the abyss of "rule by man".

Next, we should understand the traditional thought of "people-based" scientifically. Confucius emphasized the people-centered doctrine, proposed "monarch is boat and people is water, while water can carry a boat, and it can also overturn the boat" and "if the people live a wealthy life, how could the monarch live without abundance? If the people did not live a wealthy life, how could the monarch live with abundance?", and asked the ruler to "exercise government by means of virtue" and "love people and punish cautiously". The "benevolence government" of Confucian believes that the people are the foundation of the state and the trend of popular sentiment is an anchor of safety of state and the monarch. Although the people-centered doctrine reflects the feudal thought of being ruled by monarch, its value goal is consistent with those in the modem rule of law. The democratic thought in modern China were born under the influence of "western doctrine", while Chinese traditional culture provided it with "native resources" to some extent. Tan Sitong proposed "At the beginning of society, there is no so-called emperor and courtiers, all people are citizens. However, citizens can not govern their life and also do not have the time to manage the affairs; therefore, all citizens select one person to be their emperor. That being said common selection, it is not the emperor who chooses citizens but the citizens select the emperor; that being said common selection, the citizens also can abolish the emperor." In some sense, the modern rule of law based on rights is a modern inheritance or acceptance to people-centered doctrine in traditional political culture.

\section{B. Scientifically Treat the Western Culture}

"As far as western modern culture is concerned, that is, the modernized culture with western tradition contains the elements of eternity and humanity, which can be exploited by other nations, and also contains the elements of times for others to refer to and absorb. But it does not mean that it can be applicable to other modern nations and states, because it also has a unique national identity. ${ }^{2}$ Therefore, Toynbee, a famous British historian, once said: once a factor that does not bring harm or even bring rich in the civilization system breaks away from the restriction of this civilization framework and involves in the other civilization system, it is likely to be fatal to this civilization system, because there is no relative mechanism to restrict it in this civilization. As a result, 'one man's meat may well be another man's poison'."3 For western culture, we should not only see the commonness and broaden our mind to boldly absorb, but also see the difference and make use of it selectively.

\section{CONSTRUCT THE SOCIETY FOUNDATION OF THE LEGAL Culture}

The legal culture must be based on a solid social foundation. To build a socialist legal culture with Chinese characteristics, we must build a social foundation in conformity with it. The legal culture has been developing accompanied by the civil society. In 2004, Edwards, the American scholar, published a book called Civil Society, which classified all kinds of the existing civil society views into three categories: the first emphasizes the association ecology, which regards the civil society as a third sector that is independent of the state system and market system and is composed of various society organizations; the second emphasizes the value orientation, which regards the civil society as a good society based on the universal values, social capital and moral consensus; the third emphasizes the public domain, which regards the civil society as a public platform for public consultation and rational dialogue to express the subjective awareness of citizens. ${ }^{4}$ Regardless of as a third sector that is independent of the state and market or a platform to express the subjective awareness of citizens, civil society is an essential social soil for the formation and development of legal culture. Therefore, we must foster the modern citizens with independent fair, right consciousness and value pursuit of fairness and justice and build civil society by perfecting the market economy system and improving the intermediate organizations and mass organizations in society.

\section{CREATE A LEGAL ENVIRONMENT FOR THE DEVELOPMENT OF LEGAL CULTURE}

The environment can shape people and also can cultivate culture. The development of legal culture needs to create a good legal environment and legal atmosphere. First of all, the rulers shall take the lead in abiding by the law. The Communist Party of China is the decision-maker and organizer of the construction of the rule of law in China, and should also be a demonstrator and leader of keeping the law and protecting the law. The ruling party's behavior would have a strong demonstration effect to the whole nation so that the ruling party should follow the requirements of scientific, democratic and law-based governance, take action within the scope of constitutional law, set an example, take the lead in upholding the authority and dignity of the Constitution and the law. Secondly, the government shall perform their official duties according to law. Because government agencies and their functional departments are numerous, involving all walks of life and all fields, they are closely related to the people. So the demonstration effect of government agencies and their staff is the most extensive and influential. People's understanding on national policies and laws is mostly derived from the behavior and work style of the government organs. "To rule is to set straight. If you give an upright lead, who will dare walk crooked." "If the ruler himself is upright all will go well even though he does not give orders. But if he himself is not upright, even though he gives order, they will not be obey." government can not perform their official duties according to law and they suppress law with power and take policy to replace law, people will doubt the authority and effectiveness of the law, which leads to people's contempt for law and hinders people's recognition of the culture of the rule of law. The law-based administration of government not only plays a leading role in the demonstration, but also the guarantee for ordinary people to deal with things according to law. Therefore, the cultivation of the rule of law culture must be the first choice to build a government under the rule of law. Finally, the judicial authority shall make judicial justices and judicial justices are the foundation of social justice. "The terrible consequence of an unjust judgment equals to 10 times crime, 
because the crime only pollutes the flow, but the inequitable judgment will pollute the source of water". Therefore, only the judicial justices can keep the dignity and authority of law. People will believe in law and respect for law, and consciously abide by law, use the law, protect the law so that rule of law can be deeply rooted in the hearts of the people and a culture of rule by law can be created. To cultivate justice and rule of law culture, we should adhere to the focus of fairness and justice. To maintain the fair and justice of the society is the sacred mission of the rule of law and the core value of the culture of the rule of law.

\section{AdHERE TO CUltivating THE CUlture OF RUle By} LAW OF PEOPLE AS THE BASIC AND FUNDAMENTAL FOOTHOLD

Culture needs to be led, but culture must not be limited to the elite. Culture must be deeply rooted among the masses and will become a vibrant and vigorous culture. As a qualified citizen of modern society, it is necessary for us to have a good rule of law culture and legal quality to adapt to the democratic rule of law in modern society. At the same time, because the role of citizenship has included absorb all kinds of groups (such as party and political officials, judicial personnel and ordinary people, the majority of Internet users and so on) and has high coverage, therefore, we must always put the cultivation of the culture of rule by law of citizens as the starting point and foothold of socialist legal culture construction with Chinese characteristics.

\section{A. Effectively and Continually Promote the "Legal Publicity and Education Project" for the Whole People.}

It is suggested to change the name of "legal publicity and education" which has lasted for over 30 years to "rule of law publicity and education", so as to achieve the transformation from "legal thinking" to "rule of law thinking" and better play the role of propaganda and education in rule of law culture. At the same time, we should strengthen the publicity and education for idea of rule of law. The previous rule of law education activities focused on the understanding and observation for the current legal provisions and did not pay attention to cultivate the concept of the rule of law, causing that many people only mastered the knowledge of the law system but did not really understand the culture of rule by law behind the legal knowledge. Therefore, we should transform our ideas and focus on the education of citizen's rule of law culture and cultivation of the idea of rule of law and let the rule of law be deeply rooted in the hearts of every member of society.

\section{B. Optimize the Content of Legal Publicity and Education.}

In the past, the legal education activities took more consideration on obligation than rights, resulting in the dislocation of rights and obligations, which made people think that the law was merely a rule of restricting people's behavior and they themselves were just the subject of obligation. As a result, people had resistance to law. Therefore, we shall optimize the content of legal education, take the right education as the focus of legal education, make people know what rights they have, how to exercise the rights and how to maintain their rights, which will mobilize the people's enthusiasm of learning and using the law and contribute to the formation of the legal culture.

\section{Insisting on Cultivating the Network Culture of Rule by Law as an Urgent and Important Subject}

Along with the rapid development of the Internet, the proportion of netizens to the total number of citizens is increasing. According to the survey report by China Internet Network Information Center in 2016: by the end of June 2016, there have been 710 million netizens in China, with the growth rate of $3.1 \%$ in half a year, and the Internet penetration had been $51.7 \%$, increasing by 1.3 percentage points from the end of $2015 .^{7}$ The network has become an indispensable part of the national life, and the network media has increasingly affected our life. The network media also brings negative energy such as internet obscenity, internet fraud, internet rumors and so on while bring us efficient and convenient knowledge information and rich and colorful spiritual life, which seriously affects the social order. Therefore, we must accelerate the improvement of relevant legislation in cyberspace and provide clear, rigorous and operable norms of law ruling to regulate people's online behavior, strike hard to crack down on illegal and criminal activities in the field of online media, and mobilize social forces to create a good atmosphere for cultivating a network culture of rule by law and building a network civilization of rule of law. Moreover, we shall make full use of the medium of the Internet to complete the promotion and popularization of legal culture.

\section{CONCLUSION}

At present, the construction of socialist legal culture with Chinese characteristics generally has obvious characteristics of initialization, transitivity, progressivity and long term. It will necessarily go through a long and complicated process, and cannot be achieved overnight and accomplished at one stroke. Therefore, in the process of cultivating and developing the socialist legal culture with Chinese characteristics, we shall not only have the sense of urgency of the times, but also recognize the long term and arduousness of the tasks.

\section{REFERENCES}

[1] Li Yuqing, The Value of Traditional Confucianism for Construction of the Law Culture [J] Jouna; of East China University of Science and Technology (social science edition), 2010(3).

[2] Li Yuqing: The Blending and Choice of the Century, Anhui University Press, 1997 edition.

[3] Li Yuqing: The Blending and Choice of the Century, Anhui University Press, 1997 edition.

[4] Edwards, Volume one of Civil Society, translated by Chen Yimei, written into the volume 2 of China Nonprofit Review, Beijing: Social Sciences Academic Press, 2008 edition, page 110-142.

[5] Notes and Interpretation of Analects of Confucius, Beijing Zhonghua Book Company, 1980 edition, page 129

[6] Notes and Interpretation of Analects of Confucius, Beijing Zhonghua Book Company, 1980 edition, page 129.

[7] China Internet Network Information Center http://www.199it.com/archives/502874.html 